\title{
Mega-Dams in the Brazilian Amazon: towards a green, sustainable and inclusive socio- economic paradigm?
}

Riccardo Luporini and Paula Cruz 


\section{About the BRICS Policy Center}

The BRICS Policy Center is dedicated to the study of the BRICS countries (Brazil, Russia, India, China and South Africa) and other middle powers, and is administered by the Institute of International Relations at PUC-Rio (IRI), in collaboration with the Instituto Pereira Passos (IPP).

All papers are submited to external evaluation before published. The opinions expressed herein are the sole responsibility of the author and does not necessarily reflect the position of the institutions involved.

\section{BRICS Policy Center/Centro de Estudos e}

\section{Pesquisas BRICS}

Rua Dona Mariana, 63 - Botafogo - Rio de Janeiro/RJ Telefone: (21) 2535-0447 / CEP/ZIP CODE: 22280-020 www.bricspolicycenter.org / bpc@bricspolicycenter.org

\section{BPC Team}

\section{GENERAL SUPERVISOR}

Paulo Esteves

\section{ADMINISTRATIVE COORDINATOR}

Lia Frota e Lopes

\section{ADMINISTRATIVE ASSISTANT}

Bruna Risieri

\section{COMMUNICATION ANALYST}

Camila Bourgard

\section{DESIGN AND PUBLICATION}

Felipe dos Santos

Aline Aguiar

BPC Policy Brief V.5. N.10 - August September/2015. Rio de Janeiro. PUC. BRICS Policy Center

ISSN: 2318-1818

22P ; 29,7 CM

1. Mega-Dam 2. Brazilian Amazon

3. Sustainable development

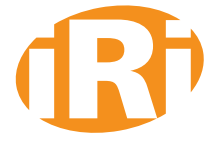

Instituto de Relações Internacionais
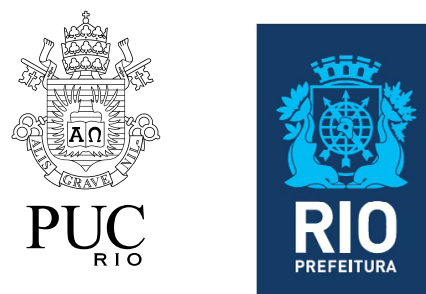

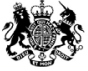

Department for International Development

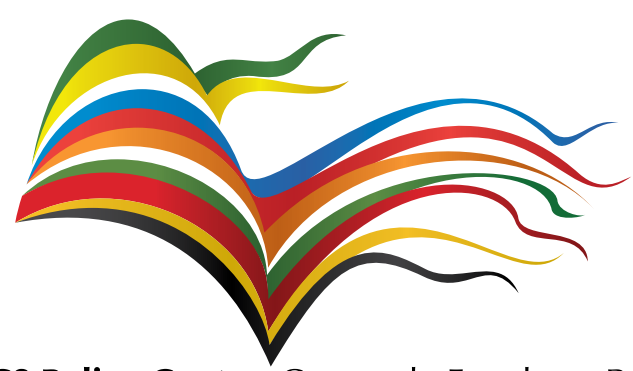

BRICS Policy Center Centro de Estudos e Pesquisas - BRICS

\section{Research Unit Innovation Systems and Governance for Development}

\section{Team}

SUPERVISOR

Luis Manuel Fernandes

COORDINATOR/RESEARCHER

Paula Cruz 


\section{Summary}

1. Introduction

2. Mega-dams in the Brazilian Amazon: assessing a controversial debate

3. Recomendations and final remarks 


\section{Executive Summary}

In the last few decades, and especially in the wake of the recent economic crisis, the global economic landscape has been altered while developing countries, particularly those in the BRICS group, have increased their economic and political power. The recent crisis, however, is not only economic or financial; today's world faces a major socio-environmental crisis. The existing economic system based on the overwhelming dominance of nature and ruthless exploitation of natural resources appears to have exceeded the resistance limits of our planet. It is now urgently necessary to question our current system of production and to pursue innovative economic and social initiatives aimed at forging new developmental patterns that are both sustainable and inclusive. In light of the increasing economic and bargaining power of the BRICS countries, this Policy Brief argues that the BRICS have the capacity to lead this process of change, and that Brazil, in particular, should play a leading role in this socio-economic transformation.

However, in their pursuit of high and stable economic growth, Brazil and the other BRICS countries have played an active role in damaging the environment through mega-development projects that are usually far from being green and sustainable. A particularly egregious example of environmentally irresponsible development in a BRICS country is the mega-dams projects in the Brazilian Amazon, which has caused significant socio-environmental harm to the irreplaceable Amazon Basin Biome. This Policy Brief aims to analyze both the benefits and harms of this project. We argue that, in the long run, Brazil should attempt to regain its environmental leadership at the global level by conceiving and gradually applying a new development approach to the Amazon. Such an approach should utilize local, small-scale development projects. The other BRICS and emerging countries may then follow the Brazilian example to initiate a shift towards a new green, sustainable and inclusive socio-economic paradigm on a global scale. 


\section{Mega-Dams in the Brazilian Amazon: towards a green, sustainable and inclusive socio-economic paradigm? ${ }^{1}$}

\section{Introduction}

Along with the recent financial and economic crisis, we face a major socio-environmental crisis on a global scale. Impending climate change and the shared responsibilities it necessitates in countries at different levels of development are now important issues on the international political agenda. Many scholars and experts ascribe this severe socio-environmental crisis to the production, distribution, and consumption modalities of capitalism. Under the neoliberal capitalist logic, the relationship between human beings and nature is characterized by dominance and exploitation (see, for example, Soares and Cassiolato 2015). Under the current capitalist global model, the rich grow richer and the poor grow poorer as the economy grows unfettered ${ }^{2}$. This unlimited economic growth and industrialization is incompatible with the finiteness of natural resources available on our planet ${ }^{3}$.

Until recently the Global North was primarily accountable for the serious socio-environmental impacts resulting from human-led development, but in today's world the relentless pursuit of

(1) The authors are grateful to Elena Bizzi and Isabella Todaro for their careful work in the finalization of this Policy Brief.

(2) David Harvey (2014) calls it "accumulation by dispossession", which results in a centralization of wealth and power in the hands of a few by dispossessing the public of their wealth or land mainly through processes of privatization, financialization, and commodification of public assets and natural resources. The latter have been deeply accentuated under the neoliberal capitalist doctrine.

(3) In 2002, the Nobel Prize chemist Paul Crutzen suggested that we had left the Holocene and had entered a new Epoch, the "Anthropocene", because of the global environmental effects of increased human population and economic development. On this concept, see Zalasiewic 2011. 
economic growth by developing countries also poses a substantial threat to a sustainable future of responsible natural resource management. As they attempt to economically catch up to the Global North, these emerging countries are indeed contributing to the degradation of the environment. China and Russia are among the top five greenhouse gas emitters, and all the BRICS countries are utilizing mega-development projects that have severe socio-environmental impacts. Such an aggressive approach to the environment is informed by the neoliberal techno-globalism that currently dominates the international economic system. Under the influence and lobbying of corporative and private interests, transnational corporations and international organizations such as development banks and financial institutions regularly play a major role in financing megaprojects that contribute to the degradation of the environment at the cost of the most marginalized groups in the developing world.

As the Paris Climate Change Conference draws nearer, the attention of the international community is primarily focused on global warming and the dangers of climate change. However, earth resistance limits are being tested in many other ways; limitless extraction of non-renewable resources, intensive agricultural systems, deforestation, disarticulated urbanization, and the extensive proliferation of large-scale development projects all harm the environment, asking more of the earth than it has to offer. In this process of relentless exploitation, numerous vulnerable human groups, minorities, local traditional communities and indigenous peoples are most affected. The survival and subsistence needs of these populations are continuously compromised by the expropriation, dispossession, and degradation of natural resources by large transnational corporations or state-owned enterprises. The case of mega-dams in the Brazilian Amazon illustrates the socio-environmental impacts of mega-development projects in the Global South. It also illuminates the tension between developing countries' current development strategies and the necessity to pursue a green, sustainable and inclusive socio-economic paradigm in the $21^{\text {st }}$ century.

\section{Mega-dams in the Brazilian Amazon: assessing a controversial debate}

The Amazon is the largest existing tropical rainforest and a hotspot of biodiversity. However, under the current neoliberal economic system - and its implacable demand for commodities and natural resources - even this unique biome appears to have been transformed into a 'new global economic frontier'. After the Second World War, newly founded international financial institutions started to fund various development projects in emerging countries aimed at fostering the accumulation of capital on a global scale through the widespread extraction and appropriation of natural resources. The Amazon was integrated in this new international production system as a supplier of raw materials with a low aggregate value but a high-energy content (Bermann et al2010). Minerals, such as iron, bauxite and zinc, were the first commodities to be extracted, followed by oil and natural gas. Then the high hydropower potential of the Amazon's rivers started to be exploited. Over the last decades, this process of exploitation has been gradually intensified as transnational corporations and foreign governments, especially China, have taken part in designing and implementing megadevelopment projects in the region.

Mega-development projects can be defined as extremely large-scale projects that use sophisticated equipment and technologies, usually imported from the Global North, that require extremely high investments through coordinated flows of international finance capital (Gellert and Lynch 2003: 16). This type of project usually has massive impacts on the environment and 
surrounding populations, greatly affecting social and public expenditures. There are two main types of mega-development projects in the Amazon: infrastructure projects and extraction projects. The former includes transportation and electrical sectors (railroads or highways, hydropower dams), and the latter refers to mineral mining and the extraction of hydrocarbons (Little, 2014:29).

About $40 \%$ of the Amazon basin is located in Brazil ${ }^{4}$. The Brazilian electrical power system is very peculiar as hydropower represents the primary source of electricity in the country. As Figure 2 shows, $64 \%$ of Brazil's total electrical energy comes from hydropower.

Figure 1: Amazon Basin

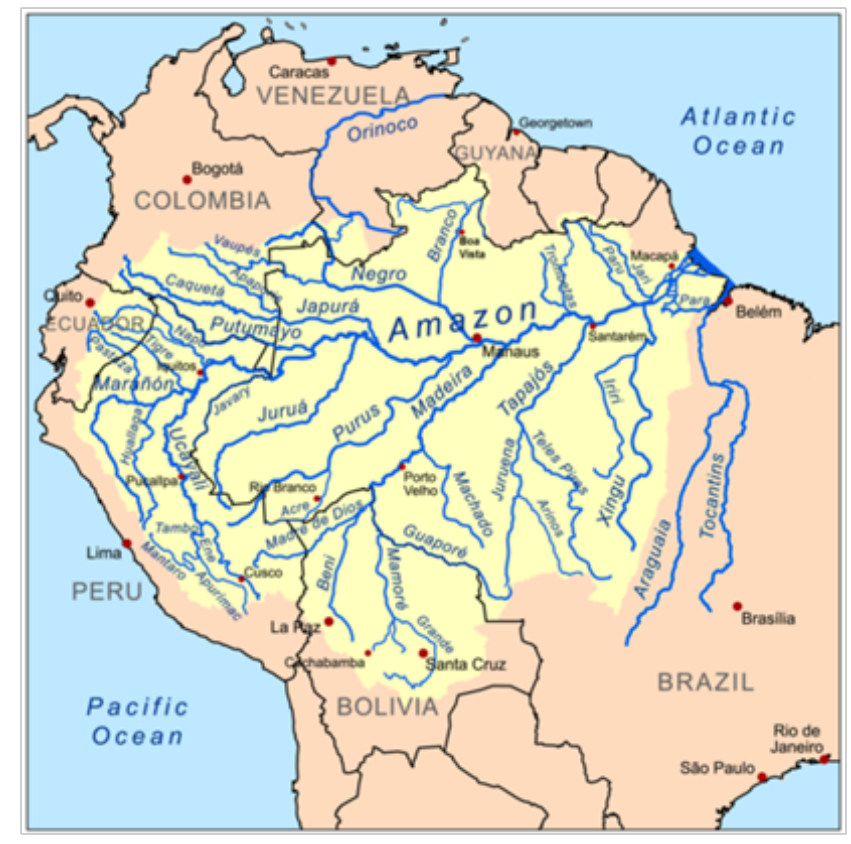

Source:Bermann (2010: 1)

Figure 2: Electricity Installed Capacity in the Brazilian National Interconnected System (SIN), December 2013

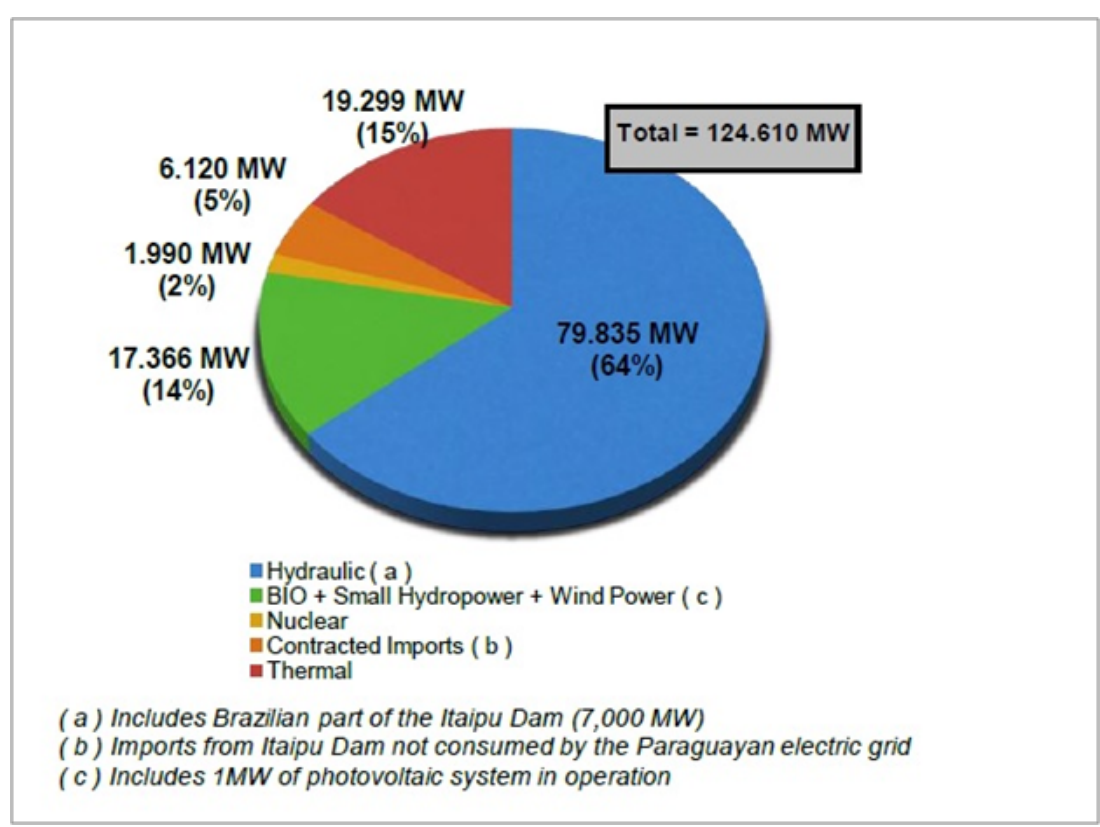

Source: MME/EPE (2014: 72). Authors'translation.

(4) Available at http://www2.ana.gov.br/Paginas/default.aspx. Accessed on 09/22/2015. 
According to the Brazilian government, this configuration of the electrical power system is justified by the extremely high hydroelectric potential in the country. As Table 1 shows, more than the $60 \%$ of this hydroelectric potential comes from Amazonian rivers such as Madeira, Xingu, Tapajós, Juruá, and Tocantins, making them the most attractive loci for the construction of mega-dams in Brazil (MME/EPE 2007: 149).

Table 1: Brazilian Hydroelectric Potential (MW)

\begin{tabular}{|c|c|c|c|c|c|}
\hline Basin & Used & Inventory & Estimated & Total & $\%$ \\
\hline Amazonas & 835 & 77.058 & 28.256 & 106.149 & 42.2 \\
\hline Paraná & 41.696 & 10.742 & 5.363 & 57.801 & 23.0 \\
\hline $\begin{array}{l}\text { Tocantins/ } \\
\text { Araguaia }\end{array}$ & 12.198 & 11.297 & 4.540 & 28.035 & 11.2 \\
\hline São Francisco & 10.290 & 5.550 & 1.917 & 17.757 & 7.1 \\
\hline $\begin{array}{l}\text { Atlântico } \\
\text { Sudeste }\end{array}$ & 4.107 & 9.501 & 1.120 & 14.728 & 5.9 \\
\hline Uruguai & 5.182 & 6.482 & 1.152 & 12.816 & 5.1 \\
\hline Atlântico Sul & 1.637 & 1.734 & 2.066 & 5.437 & 2.2 \\
\hline Atlântico Leste & 1.100 & 1.950 & 1.037 & 4.087 & 1.6 \\
\hline Paraguai & 499 & 846 & 1.757 & 3.102 & 1.2 \\
\hline Parnaíba & 225 & 819 & 0 & 1.044 & 0.4 \\
\hline Atlântico NE Oc. & 0 & 58 & 318 & 376 & 0.1 \\
\hline Atlântico NE Or. & 8 & 127 & 23 & 158 & $<0.1$ \\
\hline Total & 77.777 & 126.164 & 47.549 & 251.490 & 100.00 \\
\hline$\%$ & 30.9 & 50.2 & 18.9 & 100.0 & \\
\hline
\end{tabular}

Note: 1 - used includes existing plants in December 2005 and those under construction or with permission granted; 2 - inventory in this table indicates the minimum level of the potential studied; 3 - values consider only $50 \%$ of the power of binational exploitations; 4 - the potential of only cutting-edge plants was removed.

Source: MME/EPE (2007: 149). Authors' translation

The first dam built in the Brazilian Amazon, the Coaracy Nunes, was installed in 1975 in the State of Amapá. Since then, however, environmental social movements and indigenous-rights advocacy networks have also grown worldwide. Activists have largely disputed the effectiveness and necessity of mega-development projects in the Amazon and have managed to attain some political influence vis-à-vis important international organizations, such as the World Bank. Among other factors, this has resulted in a global temporary decline in the installation of new mega-dams. Nevertheless, the developing world, including the Brazilian Amazon, is experiencing a renaissance in mega-dam construction as the World Bank has renewed its financial support ${ }^{5}$, and new funders, such as China, have emerged.

In this section, we first give an overview of the dams that are currently in operation, under construction - or that have been planned to be built - in the Brazilian Amazon, and highlight how the Amazonian financial landscape has recently been reshaped. Subsequently, we present the main arguments used to justify the construction of mega-dams in Brazil. Then, we critically assess the idea of mega-dams as the best option of energy supply in Brazil, while pointing out some major

(5) Such 'fluctuation' in the rate of mega-dam construction in developing countries largely relates to the World Bank's approach to the topic over the years. The World Bank was the first and main financer of this kind of mega-projects until the mid-1990s, when, under pressure from global-scale campaigns, it started to withdraw its funds from controversial projects. In 2003, however, the World Bank decided to return financing mega-dams through a so-called 'high risk/high reward strategy.' See, for example, World Rivers Review 2013 
socio and environmental dangers posed by mega-dams to the Amazon biome and its population.

\section{In operation, under construction, and planned dams}

According to the Dams in Amazonia database ${ }^{6}$, there are 74 dams in operation and 31 are currently under construction in the Brazilian Legal Amazon ${ }^{7}$. The black dots in Figure 3 illustrate the former, while the orange dots represent the latter. The Tucuruí Dam on the Tocantins River and the Santo Antonio and Jirau Dams on the Madeira River are some of the largest dams in operation. Belo Monte Dam (currently under construction) stands out as the largest as well as the most controversial project. With a massive $11.233 \mathrm{MW}$ of installed power and at a cost of about US $\$ 20$ billion, Belo Monte is expected to be the third largest dam in the world ${ }^{8}$. Table 2 shows the 18 largest planned and under construction dams in the Brazilian Legal Amazon.

In addition, a significant number of mega-dams are being planned to be built within the Brazilian Legal Amazon (see the red dots in Figure 3). According to the Ten-Year Plan for Energy Expansion 2023, most of the Brazilian hydroelectric extension will take place in the Northern part of the country, especially in the Amazon (MME/EPE 2014: 82). The Plan has triggered a heated debate regarding the environmental and social impacts of constructions such as the Tapajós Complex, which will be comprised of five dams, including the São Luiz do Tapajós and the Jatoba megadams. The main points of this controversial debate will be assessed in last part of this section.

Figure 3: Dams in the Brazilian Legal Amazon

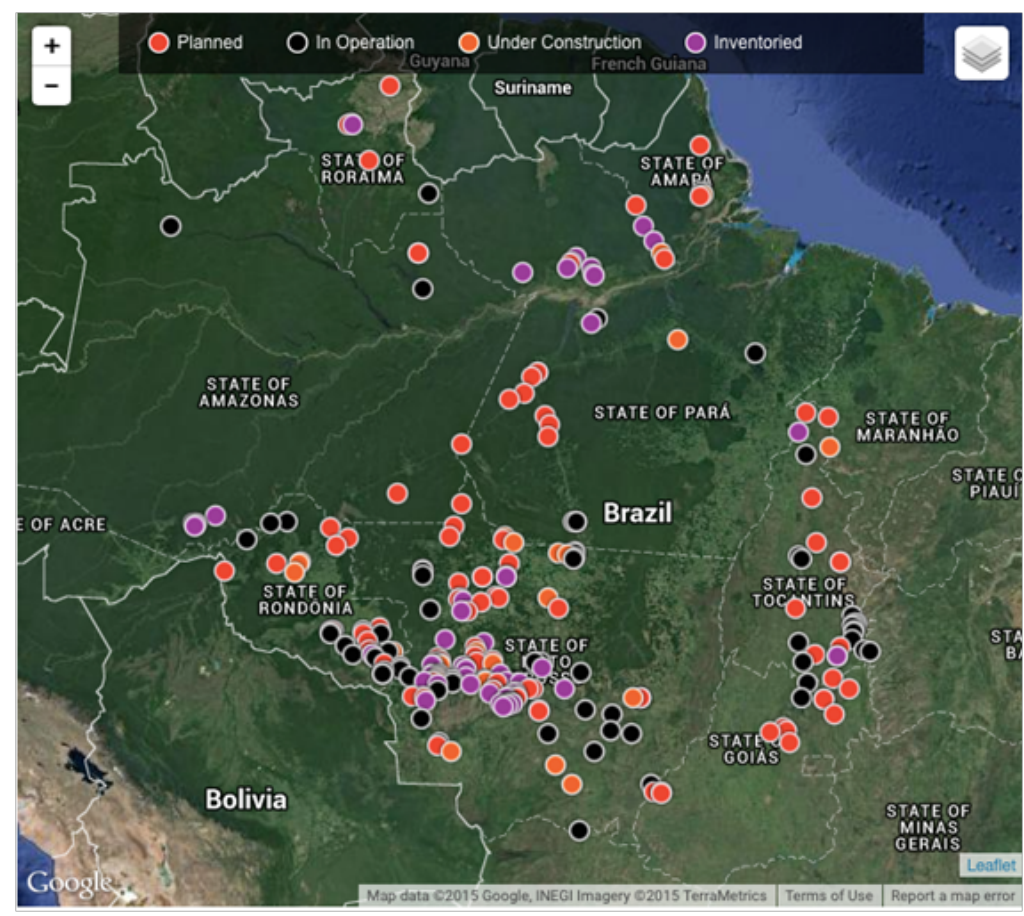

Source: Dams in Amazonia database. Available at http://dams-info.org/en. Accessed on 09/22/2015

(6) Available at http://dams-info.org/en. Accessed on 09/22/2015.

(7) The Brazilian Legal Amazon (Amazônia Legal) is an administrative unit encompassing a large part of the Amazon forest and embracing nine Brazilian States: Acre, Amapá, Amazonas, Pará, Rondônia, Roraima, Tocantins, Mato Grosso, and part of Maranhão. The 'Legal Amazon' has been initially established by the Vargas government through the Federal Law $n^{\circ} 1806$ (January 1953), with the primary purpose of better planning and implementing development projects in the region.

(8) The largest dam in the world is the Three Gorges Dam in China, followed by Itaipu Dam, which is shared by Brazil and Paraguay. 
Table 2: Planned and Under construction dams in the Brazilian Legal Amazon (> $30 \mathrm{MW}$ )

\begin{tabular}{|c|c|c|c|c|c|c|c|}
\hline $\mathbf{N}^{\circ}$ & Name & State & River & $\begin{array}{l}\text { Installed } \\
\text { capacity } \\
\text { (MW) }\end{array}$ & $\begin{array}{l}\text { Reservoir } \\
\text { area }\left(\mathbf{k m}^{2}\right)\end{array}$ & Situation & $\begin{array}{l}\text { Expected } \\
\text { year of } \\
\text { completion }\end{array}$ \\
\hline 1 & Água Limpa & Mato Grosso & Rio das Mortes & 380 & 17.9 & Planned & 2020 \\
\hline 2 & Belo Monte & Pará & Xingu River & 11,233 & 516 & Under construction & 2015 \\
\hline 3 & Bem Querer & Roraima & Branco River & 708 & 559.1 & Planned & 2021 \\
\hline 4 & $\begin{array}{l}\text { Cachoeira } \\
\text { Caldeirão }\end{array}$ & Amapá & Araguari River & 219 & 48 & Planned & 2017 \\
\hline 5 & Castanheira & Mato Grosso & Arinos River & 192 & 100 & Planned & 2021 \\
\hline 6 & Colider & Mato Grosso & Teles Pires River & 300 & 171.1 & Under construction & 2015 \\
\hline 7 & Ferreira Gomes & Amapá & Araguari River & 252 & 17.72 & Under construction & 2015 \\
\hline 8 & Jatobá & Pará & Topajós River & 2,338 & 646 & Planned & 2020 \\
\hline 9 & Marabá & Pará & Tocantins River & 2,160 & $1,115.4$ & Planned & 2022 \\
\hline 10 & $\begin{array}{l}\text { Foz do Apiacás } \\
\text { [Salto Apiacás] }\end{array}$ & Mato Grosso & Apiacás River & 230 & 89.6 & Planned & 2016 \\
\hline 11 & $\begin{array}{c}\text { Salto Augusto } \\
\text { Baixo }\end{array}$ & Mato Grosso & Juruena River & 1,461 & 107 & Planned & 2022 \\
\hline 12 & $\begin{array}{l}\text { Salto Antonio } \\
\text { do Jari }\end{array}$ & Pará/Amapá & Jari River & 370 & 31.7 & Under construction & 2015 \\
\hline 13 & $\begin{array}{l}\text { São Luiz do } \\
\text { Tapajós }\end{array}$ & Pará & Topajós River & 6,133 & 722 & Planned & 2019 \\
\hline 14 & São Manoel & Mato Grosso & Teles Pires River & 700 & 53 & Under construction & 2018 \\
\hline 15 & São Simão Alto & Mato Grosso & Juruena River & 3,509 & $>1,000$ & Planned & 2022 \\
\hline 16 & Sinop & Mato Grosso & Teles Pires River & 400 & 329,6 & Under construction & 2018 \\
\hline 17 & Tabajara & Rondônia & Ji-Paraná River & 350 & & Planned & 2020 \\
\hline 18 & Teles Pires & Mato Grosso & Teles Pires River & 1,820 & 151.8 & Under construction & 2015 \\
\hline
\end{tabular}
Source: Fearnside (2015: 25). Authors'translation

\section{Financial landscape}

Recent transformations in the international political-economic system have also reshaped the Amazonian financial landscape. Until the 1990s, the G7 countries were the main funders of megaprojects in the Amazon, and often claimed to be the 'protectors' of this region. However, in the aftermath of the recent financial crisis, this is no longer the case ${ }^{9}$. As emergent economic powers, especially the BRICS group, have increased their investments at home and abroad, Brazil and China have become the leading investors in the Amazon Region.

Mega-development projects in the Amazon are integral to the current Brazilian development strategy. In fact, Brazil is investing a significant amount of public funds in these projects, mainly through the Growth Acceleration Program, which has been realized in two phases: PAC I (20072010) and PAC II (2011-2014) ${ }^{10}$. The Brazilian Development Bank (BNDES) is another large investor in these projects, especially in the electricity sector ${ }^{11}$. In particular, BNDES has recently financed the largest mega-dams in the Brazilian Amazon through significant long-term loans. For example,

(9) In 1994, the G-7 group launched the Pilot Program for the Protection of Brazilian Tropical Forest (PPG-7). As Giorgio de Antoni (2010) put it, the launch of the PPG-7 marked the definitive transition from a conservationist ideology to the introduction of market economy in the Amazon region. Nevertheless, PPG-7 was permanently closed in September 2009.

(10) On PAC, see http://www.pac.gov.br.

(11) BNDES is a Brazilian public bank with a private legal status and internal control over its capital investments. On BNDES, see http://www.bndes.gov.br. 
it granted $R \$ 6.1$ to build the Santo Antonio Dam, $R \$ 9.5$ billion to build the Jirau Dam, and $R \$ 22.5$ billion to Norte Energia S.A. to build the Belo Monte Dam.

As it has grown to be an impressive economic power, China has also become an important investor in the Amazon. The Chinese are interested in gaining access to energy and natural resources that are strategic for its continuous economic expansion (Hochstetler 2014: 3-4, Little 2014: 56-58). Table 3 shows the capital investments between China and the Amazonian countries from 2006 to 2010. In the same period, China invested more than US\$600 million only in the Brazilian Amazon.

Table 3: Capital Investments between China and Amazonian Countries - 2006-2010 (in millions of US\$)

\begin{tabular}{llll}
\hline Brazil to China & 234.83 & 607,92 & China to Brazil \\
\hline Venezuela to China & 10.45 & 228,34 & China to Venezuela \\
Peru to China & 11.65 & 191,47 & China to Peru \\
\hline Bolivia to China & 11.65 & 46,01 & China to Bolivia \\
Ecuador to China & 3.85 & 14,58 & China to Equador \\
Colombia to China & 0.64 & 12.23 & China to Colombia \\
Latin America/Caribbean to China & $\mathbf{5 8 4 . 0 0}$ & $\mathbf{1 . 4 4 0 , 2 3}$ & China to Latin America/Caribbean \\
\hline
\end{tabular}

Source: Little (2014: 57)

It is likely that the Chinese investments in the Brazilian Amazon will continue to grow in the next few years as Brazil and China have attempted to strengthen their political and economic relations. Currently, China is already Brazil's main commercial partner. In addition, on May 19 ${ }^{\text {th }} 2015$, the two countries signed 35 bilateral agreements that totaled US\$53 billion over a variety of sectors, including a memorandum of understanding particularly focused on the Brazilian Legal Amazon ${ }^{12}$.

The New Development Bank (NDB) created by the BRICS countries in 2014 may also be a source of funds for development projects in the Amazon. Aimed at financing infrastructure and sustainable development projects, the NDB is likely to play a significant role in the Amazonian financial landscape in the near future.

\section{Why Brazil Needs Mega-Dams in the Amazon}

In response to recent criticisms against mega-dams projects in developing countries, the President of the International Commission on Large Dams (ICOLD) Adama Nombre stated that the developing world is trying to 'catch up' as fast as possible with the economic development of Europe and the West. But we have 300 years start on them and we have experimented with many different ways of building the necessary infrastructure for our current comfortable existence using most of the world's resources and energy. Are we occupying the moral high ground in deciding that others should not also have access to power and water in abundance ${ }^{13}$

According to data from the Brazilian National Energy Plan 2030, and shown in Table 4, in the last four decades final energy consumption in Brazil has increased $3 \%$ per year, while final electricity consumption has grown $6.7 \%$ per year. Additionally, according to the latest official projections

(12) Available at: http://g1.globo.com/economia/noticia/2015/05/veja-os-setores-atingidos-pelos-35-acordosassinados-por-brasil-e-china.html. Accessed on 22/09/2015.

(13) Interview published at the International Water Power \& Dam Construction webpage on 06/25/2014. Available at http://www.waterpowermagazine.com/features/featureoxford-study-on-large-dams-the-right-to-reply-4302108/. Accessed on 09/22/2015. 
included in the PDE 2023, the demand for energy and, specifically, electricity will continue to grow rapidly. It is expected that Brazil will be able to meet this demand by adding a little more than 100 TWh per year to its installed generating capacity for the next decade (MME/EPE 2014: 34-37).

Table 4: Evolution of final energy consumption in Brazil

\begin{tabular}{|c|c|c|c|c|c|}
\hline & 1970 & 1980 & 1990 & 2005 & $\begin{array}{c}\Delta \% \text { per year } \\
1970-2005\end{array}$ \\
\hline Oil derivates & 21,040 & 44,770 & 44,944 & 66,875 & 3.4 \\
\hline Electricity & 3,231 & 10,189 & 18,123 & 31,103 & 6.7 \\
\hline Sugar cane derivates ${ }^{1}$ & 3,158 & 6,221 & 10,414 & 20,046 & 5.4 \\
\hline Wood & 28,345 & 21,862 & 15,636 & 16,119 & $-2.9^{2}$ \\
\hline Natural gas & 3 & 320 & 1,385 & 9,411 & $14.5^{3}$ \\
\hline Others $^{4}$ & 3,306 & 9,506 & 15,038 & 21,490 & 5.5 \\
\hline TOTAL & 59,083 & 92,868 & 105,504 & 165,044 & 3.0 \\
\hline
\end{tabular}

Note: 1 - Including ethanol; 2 - Tax from 1970-1990; 3 - Tax from 1980-2005; 4 - Others: including coal (6.0\% of total consumption in 2005)

Source: MME/EPE (2007: 56) Author's translation

As the aforementioned official reports demonstrate, the Brazilian government has regarded mega-development projects as the main solution to keep up with the growing energy demands. Small-scale projects have been largely neglected. Yet, we argue that they are a viable alternative to generate energy on a local scale. Although Brazil seems to have other options for expanding its electrical energy supply, hydropower energy has nevertheless always been regarded a top priority in the country. The government often states that it favors hydropower for its renewability, availability and for the moderate cost of mega-dams when compared to other potential sources.

Compared to non-renewable sources, such as fossil-fuel powered plants, hydropower is considered to be much cleaner, because it is renewable and produces less Carbon Dioxide (CO2) emissions ${ }^{14}$. Accordingly, the PNE 2030 states that a reduction in the use of the hydroelectric potential would lead to an increase in the installation of thermal power plants with a direct effect on Brazilian CO2 emissions (MME/EPE 2007: 53). The PNE 2030 acknowledges that mega-dams are harmful to the environment in different ways, but argues that hydropower should not be discarded as a viable option because 'every energy source produces impacts on the environment' (MME/ EPE 2007: 147). Instead, the Plan argues that environmental damages should be analyzed with an eye towards future energy scarcity and energy generation costs (which are low in the case of hydropower). Additionally, the Brazilian government claims that dams are installed in conjunction with assorted socio-environmental projects that aim to preserve the socio-biodiversity of the surrounding area (MME/EPE 2007: 145-151).

Compared with other renewable resources such as biomass, wind and solar power, hydropower is considered to be easier to access and to have a much higher potential capacity. Although the proportion of electricity generated from other renewable sources is increasing significantly (it may soon constitute $20 \%$ of its total capacity), the government contends that it is not yet a real alternative to hydropower (MME/EPE 2014: 89-91). Brazil has one of the greatest hydropower potential capacities in the world, and, contrary to many developed countries, a large amount of this potential capacity (the majority of which is located in the Amazon basin) has yet to be explored.

(14) Hydroelectric dams can even generate certified emission reduction credits through the Clean Development Mechanism (CDM) of the Kyoto Protocol. On the CDM, see: https://cdm.unfccc.int 
Mega-dam projects supposedly play a positive role in the development of poor regions in which they are built; this may also be the case for mega-dams in the Amazon basin. Mega-dams usually require an enormous investment of capital, which produces relevant economic externalities to the benefit of the local population. In line with this view, the PNE 2030 concludes that the Human Development Index in urban centers near mega-dams is higher than in other cities of same regions (MME/EPE 2007: 146). Moreover, mega-dam projects are often praised for attracting foreign investments and creating new jobs. Indeed, more than 25,000 laborers are currently working on the construction of the Belo Monte dam.

To summarize, proponents of mega-dams in the Brazilian Amazon argue that:

a. The high demand for economic growth, development, and energy supply in Brazil presupposes mega-development projects. Small-scale local projects cannot constitute viable alternatives;

b. Compared to non-renewable sources of electrical energy, hydropower is cleaner with a substantially smaller carbon footprint;

c. Compared with other renewable sources of electrical energy, hydropower has a much larger and more accessible potential;

d. Mega-dams projects economically benefit the surrounding area, mainly through a massive investment of capital and expansion of the job market.

With such compelling arguments in mind, the question becomes: why should Brazil renounce mega-dams in the Amazon as its principal source of electrical energy?

\section{Why Brazil Does Not Need Mega-Dams in the Amazon}

It is reasonable to imagine that the Brazilian government may consider mega-dams in the Amazon to be the most suitable option to meet its increasing energy demand. Nevertheless, a first point of criticism regards the fact that much of this demand comes from the industrial sector, particularly the electro-intensive industry, which requires a remarkable amount of electrical energy for each physical unit it produces. More importantly, critics such as Célio Bermann contend that a significant portion of this energy is embedded in raw materials that are ultimately exported from Brazil. As Bermann (2012:32) put it, 'almost $8 \%$ of the electricity consumed in Brazil leaves the country incorporated into the iron ore, steel products, aluminum ingots, iron alloys, and paper and pulp that are exported.' Table 5 shows the electric power used for production and export of selected primary products in Brazil in 2008.

Table 5: Electric power used for production and export of selected primary products in Brazil 2008

\begin{tabular}{lcc}
\hline \multicolumn{1}{c}{ Products } & $\begin{array}{c}\text { Production } \\
\text { (in GWh') }\end{array}$ & $\begin{array}{c}\text { Export } \\
\text { (in GWh) }\end{array}$ \\
\hline Iron ore & $8,870.0$ & $7,140.0$ \\
\hline Steel & $18,543.8$ & $5,109.5$ \\
Iron alloys & $7,143.8$ & $2,599.1$ \\
\hline Aluminum & $25,247.2$ & $11,369.6$ \\
Pulp & $11,300.3$ & $6,133.9$ \\
Paper & $6,587.0$ & $1,230.0$ \\
\hline TOTAL & $\mathbf{7 7 , 6 9 2 . 1}$ & $\mathbf{3 3 , 5 8 2 . 2}$ \\
\hline
\end{tabular}

(1) GWh: million kWh / $0.001 \mathrm{TWh}$

Source: Bermann (2012: 31). Authors' translation 
Bergmann (2012) argues that as the electro-intensive industry continues to rapidly expand in the Brazilian productive sector, the Amazon biome is progressively becoming the supplier of electrointensive products which have low aggregate value on the one hand and high socio-environmental costs on the other. Table 6 shows the Brazilian government's projections regarding the increase in physical production of big industrial energy consumers by 2023. In line with Bermann's study, it is worth noting that the iron, cellulose, and paper industries are among those with the highest rates.

Table 6: Increase in Physical Production of Big Industrial Energy Consumers

\begin{tabular}{lcccc}
\hline Sector & $\mathbf{2 0 1 3}$ & $\begin{array}{c}\mathbf{2 0 1 7} \\
\text { mil t }\end{array}$ & $\mathbf{2 0 2 3}$ & $\begin{array}{c}\mathbf{2 0 1 3 - 2 0 2 3} \\
\text { (\% year) }\end{array}$ \\
\hline Aluminum & 1,415 & 1,467 & 1,467 & 0.4 \\
Aluminum oxide & 11,334 & 13,062 & 16,530 & 3.8 \\
Bauxite & 42,680 & 45,050 & 50,724 & 1.7 \\
Ferrous metallurgy (crude steel) & 35,472 & 43,031 & 46,650 & 2.8 \\
\hline Pelletizing & 59,232 & 77,712 & 95,472 & 4.9 \\
\hline Iron alloy & 901 & 1,308 & 1,623 & 6.1 \\
Copper & 340 & 459 & 548 & 4.9 \\
Sodium-chlorite (sodium) & 1,436 & 1,488 & 1,780 & 2.2 \\
Petrochemistry (ethylene) & 3,653 & 3,653 & 4,603 & 2.3 \\
\hline Cellulose & 14,017 & 18,563 & 23,063 & 5.1 \\
Mechanical pulp & 439 & 456 & 468 & 0.6 \\
\hline Paper & 10,565 & 12,708 & 16,794 & 4.7 \\
Cement & 71,161 & 84,947 & 109,547 & 4.4 \\
\hline
\end{tabular}

Source: MME/EPE (2014: 28) Author’s translation

A second point of criticism regards the economic inefficiency of large-scale mega-dams. This relates to at least three issues. First, large dams in developing countries usually require very high costs, and often face schedule overruns. In June 2014, Oxford University published a study (Ansar et al. 2014) on the actual costs of hydropower mega-projects. Taking the 'outside view' (also known as reference class forecasting - RCF), the study was based on data collected from 245 dams built in 65 different countries from 1934 to 2007 . The study found that even before accounting for negative environmental and social externalities, the actual construction costs of large dams are too high to yield a positive return. As Ansar et al (2014: 6) put it, 'three out of every four large dams suffered a cost overrun in constant local currency terms' and 'actual costs were on average $96 \%$ higher than estimated costs'. Not only are large dams costly and prone to severe budget overruns, they also take a long time to build. On average, large dams take 8.6 years to be constructed, and eight out of every ten large dams face schedule overruns. Ansar et al (2014) hence conclude that, taken together, the multilevel models for cost overruns and estimated schedule suggest that increasing scale and longer time frames make large hydropower dam projects risky investments.

Secondly, scholars such as Philip Fearnside and Brent Millikan (2012) argue that seasonal patterns of river flows make mega-dams in the Amazon grossly inefficiency. Due to the seasonal variation of the Amazon River water volume, many dams in operation or under construction in the region cannot be used to their full potential during a large part of the year. The most extreme case is the Belo Monte Dam, whose huge installed capacity of 11,233 MW will remain absolutely unrealized for about 4 months per year and just partially realized for the rest of the year (Fearnside and Millikan 2012: 47-54). 
Thirdly, the Brazilian rate of energy loss during electric power distribution is one of the highest rates in the world: about $20 \%$ of the energy is lost in transmission (Rey 2012: 40-44). Heavy losses of energy during transmission increase the demand for new energy generation. Therefore, as the distance covered by the transmission lines of the National Interconnected System (SIN) is expanded in order to distribute the energy produced in the Amazon Region to its major consumers (which mostly locate on the southeast and south of the country), the probability of energy loss is significantly increased. This type of energy loss also has a direct effect on energy consumers, as the price of the electricity in Brazil remains very high and continues to increase (Rey 2012: 40-44). As we will argue in the next section, alternatively, investments in more efficient distribution means would considerably reduce the need for new installations (and subsequent social and environmental harm) in the Amazon.

In addition to being economically inefficient, mega-dams projects in the Amazon cause serious socio-environmental harm. Although they are a source of renewable energy, mega-dams are far from being 'green' and sustainable (see, for example, Bermann et al 2010, Little 2014, Fearnside 2015). The deleterious socio-environmental impacts of mega-dams are diverse. These are just some of the most worrisome effects:

- $\quad$ Deforestation, industrialization and urbanization of the Amazon rainforest;

- $\quad$ Loss of biodiversity and genetic erosion;

- $\quad$ Disruption of water flaws;

- Methane emissions in dam reservoirs;

- Encroachment onto indigenous lands, displacement and forced relocation of local communities;

- $\quad$ Rapid and haphazard urbanization of Amazonian cities, surge in violence and exploitation of workers.

The flooding of large portions of land for the construction of dam reservoirs is undoubtedly the most evident impact of mega-dams. With the inundations, loss of land and biodiversity go hand in hand with the displacement and forced relocation of indigenous people and local communities. However, it must be stressed that the impacts of these mega-dams projects are not limited to the flooded areas. Fearnside and Millikan (2012) highlight that mega-dams have serious impacts upriver and downriver from the site of the dam itself: mass reduction in fisheries, interruption of seasonal floods which fertilize the floodplain, and changes in water quality due to the release of mercury and the reduction of oxygen. All of these impacts affect the economy and endanger the lives of local communities.

As already said, one of the greatest perceived advantages of mega-dam projects is the low level of greenhouse gas emissions from hydropower plants. Hydropower is widely considered to be a clean energy source, especially in comparison to, for example, thermoelectric plants, which run on fossil fuels. However, experts argue that even in terms of $\mathrm{CO} 2$ emissions, the reality is complex. Among others, Philip Fearnside (2008) has studied the real emissions from hydropower, particularly focusing on the release of methane $(\mathrm{CH} 4)$ from the decomposition of organic material in the bottom of the mega-dams reservoirs. Many others have joined Fearnside in producing robust scientificallybased evidence on the negative environmental impacts of hydropower (see Fearnside, 2008).

In terms of the social impacts, indigenous people and local communities are the most vulnerable human groups directly affected by mega-dams in the Brazilian Amazon. Their opportunities to participate in the project planning are usually very limited, and they hardly benefit from the realization of these projects, yet their lives are deeply affected ${ }^{15}$. Also socially damaging is the exploitation

(15) See, for example: International Work Group for Indigenous Affairs at http://www.iwgia.org/index.php; Amazon Watch at http://amazonwatch.org; and Cultural Survival at http://www.culturalsurvival.org. 
of the labor force. Mega-dams laborers are often subject to inhumane working conditions, and accidents and strikes are common. Additionally, the populations of Amazonian cities such as Altamira and Porto Velho have more than doubled since the construction of the mega-dams began. The population growth in these cities is nevertheless unsustainable and has brought with it a surge in violence and illicit activities ${ }^{16}$.

In sum, mega-dams projects have been a highly destructive human intervention in the Amazon biome that puts the Amazonian ecological system and populations at risk. The main points of concern are:

a. The energy produced by mega-dams in the Brazilian Amazon is mainly used for the electrointensive industry. Meaning that the local populations hardly enjoy the benefits.

b. Mega-dams projects are characterized by economic inefficiencies such as high costs and schedule overruns, seasonal variations of water volume, and heavy losses of energy along the distribution system.

c. Mega-dams projects cause serious, widespread and assorted environmental and social damages, such as deforestation, loss of biodiversity, displacement and relocation of indigenous peoples and local communities.

In view of the aforementioned criticisms, in the next section, we aim to present some useful recommendations for the formulation and implementation of effectively green, sustainable, and inclusive public policies in Brazil.

\section{Recommendations and final remarks}

In 1997, the World Commission on Dams (WCD) was formed with the aim of researching and analyzing the environmental, social and economic impacts of large dams worldwide. Released in 2000, the WCD's final report (WCD 2000) made various recommendations to mitigate the negative impacts of current projects, and improve the planning of future mega-dams. Fifteen years later, however, those recommendations are still almost completely disregarded. In line with the WCD's report and other related studies, in this section we provide some recommendations for Brazil. Our intention is to present a useful guide to action for coping with mega-dams' negative externalities in different sectors.

First, it is imperative that the Brazilian government draws special attention to energy efficiency and conservation before expanding its energy supply. Accordingly, it should:

- $\quad$ Seriously tackle mega-dams inefficiencies such as rivers seasonality problems and wasteful energy transmission systems before expanding its electricity supply;

- $\quad$ Take into consideration all of the different complications and negative externalities related to mega-dam projects and compare them to other available electric power supply modalities ${ }^{17}$ before opting for building new large-scale dams.

(16) On recent deaths of Belo Monte workers, See: http://g1.globo.com/pa/para/noticia/2015/05/corpos-deoperarios-de-belo-monte-sao-encontrados-sem-vida-no-para.html. On deaths of Santo Antonio and Jirau workers, See: http://www.rondoniaovivo.com/noticias/obras-de-jirau-e-santo-antonio-tem-historico-de-43-mortes/131972\#. VZQMO-tN3ZI

(17) As Podcameni (2014) shows, wind energy is particularly promising in Brazil due to its natural characteristics as well as its technological capabilities related to wind power. 
Secondly, the various socio-environmental impacts of mega-dams should be contemplated during each phase of the project. In the policy making and planning phases, the Brazilian government should:

- $\quad$ Direct financing institutions, such as the BNDES, to embrace stringent environmental and social standards;

- $\quad$ Ensure that all environmental license processes of the IBAMA Institute ${ }^{18}$ are transparent and accountable via regular and effective public monitoring, and that all license conditions are duly fulfilled, including their social components;

- Safeguard active popular participation in decision making processes and engage environmental analysts;

- $\quad$ Consider ratifying the Strategic Environmental Assessment Protocol (SEA) and then persuade other South American countries to join the subscribers ${ }^{19}$.

During the realization phase, Brazil should:

- Guarantee that construction companies design and carry out efficient and innovative impact mitigation programs in line with the Basic Environmental Plans ${ }^{20}$, and that the activities of these programs be reported to and monitored by governmental agencies;

- Implement programs aimed at watching and preventing common affects related to the disarticulated urbanization of cities located in the areas surrounding mega-dams, especially increases in violence, and drug and sex trafficking.

- Inspect working conditions in mega-dams plants regularly, making sure that the working environment and procedures meet the required standards, and fining companies that violate those standards.

In addition, during all the lifetime of the mega-project, Brazil should:

- $\quad$ Strictly adhere to the 'mitigation hierarchy' principle ${ }^{21}$, with the aim of preserving the Amazon's unique biodiversity (BBOP 2012);

- $\quad$ Guarantee the right to Free, Prior and Informed Consent ${ }^{22}$ of the indigenous peoples of the Amazon, and extend it to the local and traditional communities affected by the project;

- Safeguard the participation of civil society representatives in all of the project decisionmaking process.

(18) The environmental license process of the IBAMA includes 3 different types of licenses: preliminary, installation, and operating licenses. The preliminary license should be granted only if accompanied by the according Environmental Impact Studies (EIA) and the Environmental Impact Report (RIMA). See: http://www.ibama.gov.br/licenciamento/

(19) The SEA Protocol was negotiated and signed by the UNECE countries. However, after it entered into force in 2010, the agreement became open for ratification toall UN countries, including South America.

(20) The Basic Environmental Plan is the technical document that contains all the different mitigating activities of the environmental programs included in the EIA/RIMA. This document is fundamental for the installation license to be grant by IBAMA. If the Basic Environmental Plan is not fully accomplished, the realization of the project should be denied. See: http://www.masterambiental.com.br/consultoria-ambiental/pba-plano-basico-ambientald

(21) Mitigation hierarchy is a concept and a practical tool conceived by the Business and Biodiversity Offsets Program (BBOP) aimed at limiting as far as possible the negative impacts of development projects on biodiversity. It includes four sequential steps: avoidance, minimization, rehabilitation/restoration, and offset. See: http://bbop.forest-trends.org/ pages/mitigation_hierarchy

(22) The FPIC is the right of indigenous peoples to be consulted and make free and informed choices about the development of their lands and natural resources. The right to FPIC evolved from the recognition of indigenous peoples' self-determination and is currently under debate within international law. The basic principles of FPIC are to ensure that indigenous peoples are not coerced, that their consent is sought and freely given prior to the authorization or start of any activities and after that they have received full information about the scope and impacts of the project. Here, we mention not only mere consultations, but effective negotiations aimed at reaching agreements on a variety of issues related to the construction of mega-dams in the Amazon. Governmental representatives should act as mediators during all the negotiation processes. See, for example, Khatri 2013. The extension of the FPIC to traditional local communities has been addressed in important international guidelines. See, for example, Buxton and Wilson 2013. 
Finally, the Brazilian government should be committed to funding and assuring the continuity and improvement of scientific research focused on the different socio-environmental impacts of mega-dam projects, including studies particularly attentive to methane emissions coming from dam reservoirs.

The recommendations outlined above highlight some of the most important issues that must be on the Brazilian government agenda for mitigating and preventing deleterious socio-environmental harms of mega-dams projects in the Amazon in the short and medium runs. However, a more fundamental and structural change is also needed in the long run: it concerns the consolidation of a green, sustainable, and inclusive socio-economic paradigm on a global scale. The neoSchumpeterian definition of innovation systems is particularly useful here; it advocates a reorientation of the conventional notions of 'growth' and 'development' towards a more green and sustainable understanding of socio-economic development within the new economic paradigm of the $21^{\text {st }}$ century.

Carlota Perez is a leading scholar in the neo-Schumpeterian School. Perez (2014) analyzed the history of the main technological revolutions and the related major market economy crises, which, along with a specific historical and socio-political context, have led to the advent of new economic paradigms over the history of capitalism. For Perez, major economic crises preceded and produced the conditions that led to the emergence of different Golden Ages - each one based on a new technological paradigm. She argues that the recent financial crisis and the related ICT revolution are producing the conditions for a new global, green and sustainable Golden Age. Different from the Fordist model of mass production and consumption - which requires an unlimited availability of cheap energy and natural resources and the concentration of manufacturing plants in order to achieve economies of scale - the new ICT paradigm is based on flexible production patterns in the field of energy and materials supply, counting on cheap microelectronics and telecommunications that use less of relatively more expensive energy and materials. As a result, the international division of production based on the dependency and subordination of disadvantaged poor countries, suppliers of energy or raw materials is currently being replaced by a flexible production system that affords multiple opportunities for technological development in all sectors, as well as significant inter-country differentiation. As Perez (2014: 12) puts it,

we are thus referring to a growth process that guarantees an increasing quality of life for growing proportions of the world's population through an environmentally sustainable economy. It is not just about avoiding global warming; it is also about sharing and preserving scarce natural resources and overcoming poverty.

According to her, this involves: (i) less energy and materials per unit of production, transport and consumption, with a massive increase in the productivity of resources; (ii) a significant increase in the proportion of renewable sources of energy and materials used with a clear focus on conservation; (iii) revamping all existing infrastructure to make it durable and energy efficient.

Building on Perez analysis, we believe that Brazil can - and should - play a primary role in this process of change. Over the last decades, Brazil has emerged as an environmental leader, not only hosting the UN Conferences on Sustainable Development, but also taking important and effective steps towards sustainability. Some of these important steps include a significant decrease in deforestation and the extension of Protected Areas and Indigenous Lands. On the other hand, however, Brazil's leadership in global environmental politics is seriously called into question by the realization of mega-development projects such as the Amazon mega-dams, and their pervasive social and environmental damages. In view of the current conjuncture, our last and most important recommendation is in accordance with Ferreira et. al's (2014) charge: Brazil should recover its 'hard-won environmental leadership' at the international level, and in order to do that, it should start by radically changing its policy approach to the Amazon biome. 
As already stated, a common characteristic of mega-development projects in the Amazon is that they are planned by people and organizations from outside of the Amazon. Moreover, these projects are primarily designed to meet external demands to the region. Amazonian people, their needs and their local 'best practices' are systematically neglected in the different phases of megaprojects. However, the process of development - as it aims to generate innovation - is inevitably influenced by and dependent on the local specificities of a particular territory (see, for example, Freeman 1992; Soares and Cassiolato 2015). As a corollary, meeting the demands and following the directives of giant transnational corporations, while embracing the techno-globalism patterns of development of more advanced nations, is likely to lead to failed development in the Amazon Region.

Still, should the knowledges and practices of local communities be acknowledged and integrated into an effective innovation system, Brazil's leadership in the global environmental agenda could be restored, pushing the world towards an effectively green, sustainable and inclusive socioeconomic paradigm. Small-scale, local and community-based renewable energy projects should in the long run replace mega-projects as the main strategy for development in the Amazon Region. Little (2014), for example, speaks about an 'Amazon-centric development' and a 'pan-Amazonian theory of change', and Sachs (2008) proposes that Amazonia be a 'laboratory of bio-civilizations of the future'. Of course, in order to realize these great visions, first Brazil must revise and reorient its public policies directing them to the achievement of a green, sustainable, and inclusive development strategy - one that is committed to a full environmental democracy. Lessons from the Brazilian experience may then inspire the other BRICS countries, and invigorate the search for a green, sustainable, and inclusive socio-economic paradigm on a global scale.

Does it all sound utopian? To borrow Perez's words (2014: 20), 'the best of the viable futures have to be conceived and constructed boldly. Once you identify the seeds, it is important to plant and harvest them!' Where better than the Amazon to have this plantation started? 


\section{References}

Ansar, A. et al. (2014), 'Should we build more large dams? The actual costs of hydropower megaproject development', Energy Policy.

Bermann, C. et al (2010), 'Usinas hidrelétricas na Amazônia: o futuro sob as águas'. In: Seminário Políticas Públicas e obras de infraestrutura na Amazônia. Brasília: Anais Cenários e desafios para a governançasocioambiental, pp. 1-37.

Bermann, C. (2012), 'O Setor de Eltro-intensivos'. In Moreira, P. F. (ed.) O Setor Elétrico Brasileiro e a Sustentabilidade no Século 21: Oportunidades e Desafios. Brasília: Rios Internacionais, pp. 28-34.

BBOP. Business and Biodiversity Offsets Programme (2012), Standards on Biodiversity Offsets, Forest Trends.

Buxton A. and Wilson E. (2013), 'FPIC and the extractive industries A guide to applying the spirit of free, prior and informed consent in industrial projects', IIED, available at: http://pubs.iied.org/ pdfs/16530IIED.pdf?

De Antoni, G. (2010), 'O Programa Piloto para Proteção das Florestas Tropicais do Brasil (PPG-7) e a globalização da Amazônia', Ambiente \& Sociedade, Campinas, v. XIII, n. 2, pp. 299-313.

Fearnside, P.(2015), 'Hidrelétricas na Amazônia brasileira: Questões ambientais e sociais'. In: Floriani, D and A.E. Hevia (eds.), América Latina Sociedade e Meio Ambiente: Teorias, Retóricas e Conflitos em Desenvolvimento. Curitiba: Editora da Universidade Federal do Paraná.

Fearnside, P. and Millikan B. (2012), 'Hidrelétricas na Amazônia: Fonte de Energia Limpa?' In Moreira, P. F. (ed.) O Setor Elétrico Brasileiro e a Sustentabilidade no Século 21: Oportunidades e Desafios. Brasília: Rios Internacionais, pp. 47-54.

Ferreira et al. (2014), 'Brazil’s environmental leadership at risk', Science, pp. 346-706.

Freeman C. (1992), 'The Economics of Hope: Essays on Technical Change, Economic Growth, and the Environment', Pinter Pub Ltd.

Gellert P and Lynch B. (2003), 'Mega-projects as Displacements', International Social Science Journal, 55. 175.

Harvey D. (2014), Seventeen Contradictions and the End of Capitalism. Oxford: Oxford University Press.

Hochstetler K. (2014), 'Infrastructure And Sustainable Development Goals in The BRICS-Led New Development Bank", Centre for International Governance Innovation (CIGI), Policy Brief , n.46.

Bosshard P.(2013), 'World Bank Returns to Big Dams', World Rivers Review, v. 28, n.3.

Khatri U. (2013), 'Indigenous Peoples' Right to Free, Prior, and Informed Consent in the Context of State Sponsored Development: The New Standard Set by Sarayaku V. Ecuador and its Potential to Delegitimize the Belo Monte Dam', American University International Law Review, vol. 29, n. 1. 
Little, P. (2014), Mega-development Projects in the Amazon Region: A geopolitical and socioenvironmental analysis with proposals of better government for the Amazon. Executive Summary. Available at <http://www.dar.org.pe/archivos/publicacion/145_megaproyectos_ingles_final.pdf $>$.

MME and EPE. Ministério de Minas e Energia and Empresa de Pesquisa Energética (2007), 'Plano Nacional de Energia 2030'. . (2014), 'Plano Decenal de Expansão de Energia 2023'.

Perez C. (2014), 'A Green and Socially Equitable Direction for the ICT Paradigm', Globelics Working Paper Series, N. 2014-01.

Podcameni, M. G. (2014) Sistemas de inovação e energia eólica: a experiência brasileira. Doctoral thesis. Universidade Federal do Rio de Janeiro.

Rey, O. (2012), 'Um Olhar para as Grandes Perdas de Energia no Sistema de Transmissão Elétrico Brasileiro'. In Moreira, P. F. (ed.) O Setor Elétrico Brasileiro e a Sustentabilidade no Século 21: Oportunidades e Desafios. Brasília: Rios Internacionais, pp. 40-45.

Sachs I. (2008), 'Amazônia - laboratório das biocivilizações do futuro', Biblioteca Diplô. Available at <http://diplo.org.br/imprima2646>.

Soares M. andCassiolato J. (2015), 'Crise, sustentabilidade e mudança tecnológica'. InCassiolato, J. etal., Sustentabilidade socioambiental em um contexto de crise, E-Papers.

UNECE (2010), Strategic Environmental Assessment Protocol (SEA Protocol).

UNEP (2011), Green Economy Report.

WCD. World Commission on Dams (2010), 'Dams and Development', Earthscan Publications.

Zalasiewicz J. (2011), 'The Anthropocene: a new epoch of geological time?', Royal Society Publishing. 


\section{About the author(s)}

Paula Cruz is Doctoral Candidate in International Relations at PUC-Rio (Brazil), Researcher and Coordinator of the research unit 'Innovation Systems and Governance for Development' at the BRICS Policy Center, and Editorial Assistant of the journal Contexto Internacional. She holds a Master's degree in International Relations from Rio de Janeiro State University, and a Bachelor's degree in Social Communication from the Federal University of Bahia. Currently, her main topics of study relate to the International Political Economy of Intellectual Property Rights, Scientific and Technological Cooperation among the BRICS, and the Role of Universities in Innovation Systems.

Riccardo Luporini is currently enrolled in the Master's Degree in European and International Studies (MEIS) of the University of Trento, and the International Studies and Transnational Governance Program (ISTG) of the Sant'Anna School of Advanced Studies of Pisa, both in Italy. From February to July 2015, he was an exchange student at the International Relations Institute of PUC-Rio, and a Research Assistant in the research unit 'Innovation Systems and Governance for Development' at the BRICS Policy Center. He is writing his dissertation on indigenous peoples and traditional local communities' participatory rights in relation to mega-dam projects in the Brazilian Amazon.

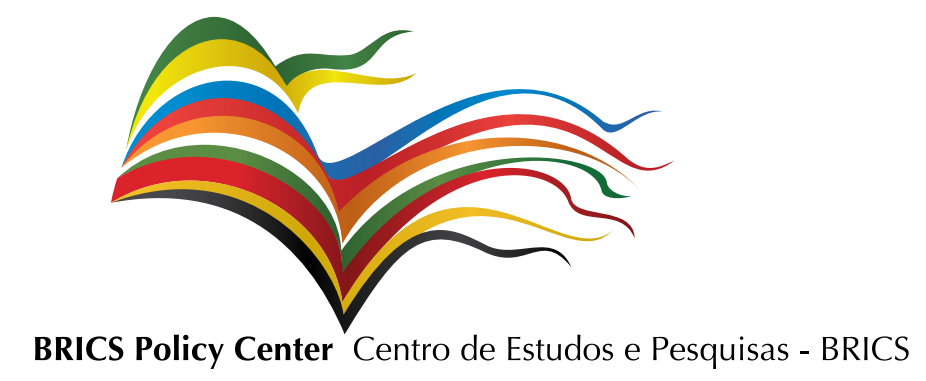

Rua Dona Mariana, 63 - Botafogo - Rio de Janeiro/RJ Telefone: (21) 2535-0447 / CEP/ZIP CODE: 22280-020 www.bricspolicycenter.org / bpc@bricspolicycenter.org
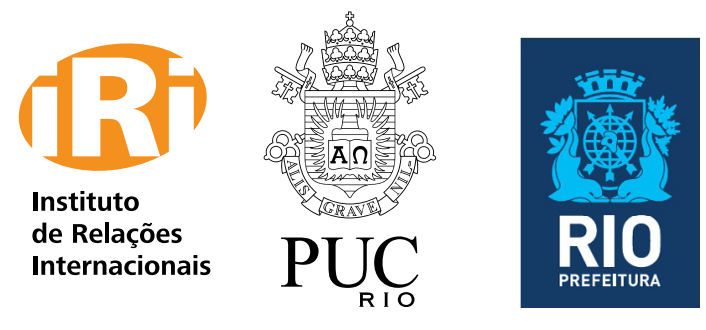

the

Department for International Development 